\title{
Media populism in Macedonia: Right-wing populist style in the coverage of the "migrant crisis"
}

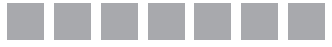 \\ Ivo Bosilkov \\ ORCID: 0000-0003-3026-2290 \\ UNIVERSITY OF MILAN, ITALY \\ UNIVERSITY OF AMSTERDAM, NETHERLANDS
}

DOI: 10.19195/1899-5101.12.2(23).6

\begin{abstract}
The communicative style used to exclude immigrants from the idea of "the people" is the scope through which right-wing media populism is measured in a case study of Macedonia, a post-communist country on the Balkan migrant route. Quantitative content analysis of articles from four Macedonian right-wing partisan news outlets $(N=409)$, demonstrates a clear change in tone in coverage of migration, marked by an increase of populism as the "migrant crisis" intensified. Logistic regression confirms that incivility, as a proxy for the intensity of partisan bias, is a significant predictor of populism, and opinion pieces have a significantly stronger populist tendency than news reports. The findings show that online news outlets, however, are not more populist than traditional print media.
\end{abstract}

KEYWORDS: populism, migration, Macedonia, media, content analysis.

\section{INTRODUCTION}

Although populism has always been an intricate part of democratic societies, its recent resurgence has highlighted the complex relationship it enjoys with democracy. The pervasiveness of populism in the realm of the political is most prominent in party dynamics (Rydgren, 2005) and voter behavior (Akkerman, Mudde, \& Zaslove, 2013), two fundamental ingredients of any democratic system. Canovan $(1999$, p. 3) calls populism "a shadow cast by democracy," encapsulating a constant tension between forces that are simultaneously constitutive of and contradictory to democracy. 
Yet, if populism is pervasive in democratic societies, its presence should be felt even beyond party politics and voting behavior. When Mudde (2004) speaks of "populist Zeitgeist," this is not limited solely to parties and voters, but also what is between them, where these actors perform their deliberative functions. After all, if one of the approaches to populism is to regard it as "rhetoric" (Barr, 2009), "discourse" (Hawkins, 2009), "language" (Kazin, 1995), then the focus should not only be on the relationship between the political actors as producers and the electorate as receivers, but also on the public space, where media act not only as transmitters of the populist message, but also amplifiers (Alvares \& Dahlgren, 2016) and even creators (Bos \& Brants, 2014).

While a great body of literature exists on populism, a much smaller portion of it is dedicated to the concept of media populism (for an overview, see Mazzoleni, Stewart, \& Horsfield, 2003; Mazzoleni, 2008), and virtually none that tackles media populism in Eastern European post-communist societies, where democracy is still not fully consolidated. The challenges in such a research endeavour are multifaceted; firstly, these states do not have a long tradition of media pluralism, and the characteristics of their media systems are still a subject of academic debate (Hallin \& Mancini, 2012), blurring the conceptual framework required to identify longterm patterns in the evolution of media populism. Secondly, the European model of right-wing populism with all its essential characteristics, as the main subject of study in Western academia (see Gidron \& Bonikowski, 2013), has so far not been smoothly translatable to Eastern Europe, where cultural and historical contingencies contributed to idiosyncratic forms of populism.

However, the recent "migrant crisis" helped to bridge this gap between Western European right-wing populism - a long time champion of anti-immigrant attitudes - and its Eastern European counterpart, thereby allowing an opportunity to investigate the rise of what Mazzoleni et al. (2003) call right-wing "neo-populist" discourse, as a stylistic manifestation of anti-immigrant sentiment in the media. This study explores the case of Macedonia, a country where migration issues have only become relevant in the public sphere after it found itself on the route of the migrant flow in 2015. The case selection is further justified as the ruling party in Macedonia at the time of the crisis has been widely regarded as populist (Surmava, 2014) and infamous for establishing a strongly partisan polarized media arena (Causidis \& Sekulovski, 2013). The combination of these factors creates a perfect setting for investigating how media populism proliferates in a non-Western context.

Hence, this study does not focus on populist rhetoric on migration by rightwing political actors, but that of right-wing partisan media in Macedonia, through analysis of their coverage on the topic for the brief period it was of high importance in the country. Apart from the novel setting, the study offers three theoretical contributions. Firstly, the content analysis shows an increase in populist reporting as the scale of the crisis burgeoned, confirming that the communicative style of populism permeates journalism in the context of growing salience of the migration 
threat. Secondly, it examines the relationship between populism and different levels of partisan bias among outlets, operationalized through incivility. Finally, it makes the important distinction between populism in traditional media (such as print newspapers) and new media (online news outlets), as well as different article types, thereby addressing existing gaps in the study of media populism. The practical implications of the findings are discussed in the final section.

\section{THEORETICAL FRAMEWORK}

The scholarly consensus has been to view populism as a "thin ideology" (Mudde \& Rovira Kaltwasser, 2011), referring to its adaptability in mixing with other ideologies which seek to exploit populism's two main features: the appeal to the people and the contempt of elites. It is this opposition that serves as a common denominator in most of the scholarly work on populism, with Mudde's (2004, p. 543) minimal definition serving as empirical foundation: "[populism is] a thin-centred ideology that considers society to be ultimately separated into two homogenous and antagonistic groups, 'the pure people' versus 'the corrupt elite' and which argues that politics should be an expression of the volonté générale of the people." Yet, there is a wide range of political actors which can embrace this principle. While the majority of populism research confines the term "political actor" to politicians directly involved in political parties and the electoral process, Rooduijn (2014) argues that if populism can be considered the property of a specific message rather than a property of an actor sending that message, as such it can be also studied outside the realm of institutionalized politics. This approach to the study of populism as a discursive phenomenon has been increasingly popular among scholars recently, as it shifts the focus to the unique contribution of communication processes to construct populist ideas. This enables researchers to study populism as content, referring to the public communication of core components of populist ideology with a characteristic set of key messages (de Vreese et al., 2018).

Building on this tradition, Rooduijn (2014) demonstrates how populism is enacted in Western European media. Yet his content analysis of manifestations of populism as rhetoric of the thin ideology fails to capture two key aspects: the ideological and the stylistic. According to Moffitt and Tormey (2014, p. 386), "for a subject notorious for its prevalence of charismatic leaders and stylistic flourishes, it's fanciful to imagine that populism can only be measured as a set of words to be counted and collated." They claim that, because the contemporary political landscape is increasingly mediated and stylized, the so-called aesthetic or performative features are particularly important. This populist political style consists of three main elements. The first one being appeal to the people, which does not necessarily assume Mudde's (2004) interpretation of elites as corrupt, rather just explains the antagonism of "the pure people" towards other groups in society, such as for example asylum seekers or immigrant workers. The second is the perception of 
crisis, breakdown and threat (Taggart, 2000), with its desired effect being to radically simplify the terms and terrain of political debate, reflected in a tendency towards simple and direct language. Finally, there is the third element called "bad manners," which emerges from the disregard of populists for "appropriate" ways of acting in the political world. Moffitt and Tormey (2014) refer to this phenomenon as coarsening of political discourse, while Canovan (1999) labels it "tabloid style."

The first two elements are essential for the symbiosis between right-wing ideology and populism. Indeed, the study of populism in Western Europe has mostly tackled the emergence of a "new" populism of right-wing parties and their agendas, focusing on the ways populist logic enhances the xenophobic spirit of radical rightwing ideology, often seen as a menace to democratic values (Meny \& Surel, 2000; Taggart, 2000). To disentangle this relationship, Jagers and Walgrave (2007) differentiate between the "thin" interpretation of populism, which only assumes appeal to the people, and a "thick" variant, which includes common anti-establishment features, but also the exclusion of certain categories of population, as "some isolated groups do not share the people's 'good' characteristics, with their values and behavior irreconcilable with people's interest," and are therefore stigmatized, defined as a threat or burden to society and blamed for all the misfortune (Jagers \& Walgrave, 2007, p. 324). While the above outlines the nature of right-wing populism, Moffitt and Tormey's (2014) third element is what ultimately translates it to the media. In fact, Krämer (2014, p. 48) defines media populism as "the use of stylistic and ideological elements by some media, namely the construction of favoritism of ingroups $[\ldots]$ reliance on charisma and group related commonsense, and appeal to moral sentiments, emotionalising, personalising and ostentatiously plain-spoken discourse." This definition distinctly evokes Moffitt and Tormey's (2014) "bad manners" component of political style: the use of slang, swearing, political incorrectness, being overly demonstrative and colourful, as opposed to "high" behaviors of rigidness, rationality, composure and technocratic language, as well as the breach of taboos, metaphors of violence and opposition of compromises (Krämer, 2014).

As the element of threat receives ever-greater attention in news coverage of migration (Thorbjornsrud, 2015), amplifying the voice of right-wing politicians who exclude immigrants from the idea of "the homogenous people," I focus on Jagers' and Walgrave's (2007) exclusionary feature, intentionally overlooked by Rooduijn in order to tap the "thin" variant of populism. This approach circumvents the analytical inconsistency emerging from the conceptual clash between the exclusionary populism of the right wing, and anti-elitist populism, as complementary to leftist ideology (Reinemann et al., 2016). Therefore, unlike Rooduijn (2014), who does not identify a specific issue in his objective to demonstrate an increase of populist discourse, I situate the research in the context of the recent European "migrant crisis," as I argue that for exclusionary populism, an out-group threat and a quickly developing ambient of crisis is required to drive media towards emulating and internalizing the populist style of political actors. As previous research shows that 
an increase of the salience of migration is associated with the populist party surge (Rydgren, 2005), it can be expected that this pattern is also replicated with media populism:

H1: A populist style in media coverage of migration has increased with the escalation of the "migrant crisis."

Mazzoleni et al. (2003) pinpoint the appropriation of populist behavior to a part of the media that has "tabloid" attributes, which do not share the elite media's striving to appear unbiased and report fairly and responsibly. This is also observed by Krämer (2014), according to whom tabloid journalism is perceived to invoke ethnic and moral community by pursuing a "moral fundamentalism," while also displaying aversion towards abstract conceptions of society, such as complex political procedures. Yet, Rooduijn (2014) finds that tabloid newspapers are no more inclined to the populist message than elite ones. This could indicate that the elite versus tabloid contrast is a simplified and perhaps even outdated perspective. A potentially confounding influence in this context is a category which, like tabloid media, rejects balanced reporting, yet is largely absent in the media populism literature: partisan media.

Apart from the occasional inadvertent populist perspective on politics due to their nature, tabloids can sometimes also provide "support for at least a wing of an established party within a two-party system" (Krämer, 2014, p. 51). This is the essence of partisan media: opinionated platforms that not only report the news but offer a distinct point of view on it, biased in favor of one party and political viewpoint (Levendusky, 2013). By design, partisan media engage in a biased story selection, reporting more heavily on topics that favor their side and downplaying stories that harm their points of view (Baum \& Groeling, 2008). Through creating a "self protecting enclave" that gives viewers an easily digestible version of an otherwise confusing political world, partisan media foster an antagonistic worldview, resulting with audience polarisation (Sunstein, 2009). This phenomenon is the outcome of an increased competition for fragmented niche audiences, pushing media figures to say more outlandish and controversial things (Gervais, 2014). Due to this, partisan media are characterized by a lack of civility, as their main distinguishing aspect from impartial nonpartisan media. In fact, Jamieson and Cappella (2009) describe the most uncivil political talk-shows (such as the Rush Limbaugh show) as also the most party-biased. From this, it can be inferred that media partisanship and incivility are correlated.

The connection between partisan media and populism is self-evident; namely, according to Jamieson and Hardy (2012, p. 413), partisan media "invite moral outrage by engaging emotion, replace argument with ridicule and ad hominem, and often invite the audience to see the political world as a Manichean place unburdened by complexity, ambiguity or common ground." Additionally, as exclusion 
is also a common property of partisan media, incivility among right-wing party biased outlets is likely to thrive in the context of a migration crisis. As Herbst (2010) argues that incivility is a weapon used strategically to rile up audiences with anger about how bad the other side is and to mobilize them, the tone in which outlets communicate anti-immigrant messages can likely determine the extent of incivility, which can simultaneously serve as an indicator of the degree of partisan bias. Thus far, there has been no significant attempt to investigate the link between populism and the intensity of partisan bias in right-wing media, but if incivility is used as a proxy indicating partisanship, the second hypothesis emerges:

\section{H2: The more uncivil partisan media are, the more populist style they will exhibit.}

In order to further advance knowledge of media populism beyond the basic dichotomy of elite and tabloid media, it is not only partisan bias that needs to be examined more closely, but also the distinction between traditional and digital media. As digitalization changed the principles of distribution and circulation of news, it prompted newspapers to reconsider their role and position in the provision of news, with inevitable implications on the political news content, and therefore the style used in its production (Trappel \& Enli, 2011). Online media are redefining the field and posing a serious challenge to the traditional written formats, refusing to adopt the standards set by newspapers and introducing a different news culture (Allan, 2002). Meanwhile, traditional media compete by implementing online media "logic", such as tapping into social media or adding user interactivity (see Saura \& Enli, 2011).

Yet, the professional features and value systems of large media organisations are fundamentally different from the new models of online outlets, represented by small newsrooms, or even bloggers and citizen journalists. Reporting on politics therefore is also different; as Matheson (2004, p. 449) argues, "there are certain conventions of the genre, including an ephemeral and informal quality [...] and often irreverent commentary or opinion." Such practice can possibly be a gateway to the populist style described above. This statement is supported by online platforms' claim for a particular authenticity of the personal, of "people in their natural dialect" (Matheson, 2004), indicating a tendency for the populist discourse. Due to its lesser concern for ethical standards compared to traditional news reporting, a looming notion exists that "online journalism is the gangly, misfit cousin of 'real' journalism [...] the internet is a breeding ground for kooks and charlatans and Web journalism operates at a level below the standards of traditional news media" (Singer, 2003, p. 151). From this, sufficient evidence of the differences between traditional print and online news outlets exists to formulate the third hypothesis:

H3: Populist style in the context of the "migrant crisis" is used more by online news outlets than traditional print outlets. 
Finally, existing studies have not sufficiently engaged with how the diffusion of populism varies across different types of news content articles. Previous research has found that there is a link between populist attributions of blame and interpretative journalism (Hameleers, Bos \& de Vreese, 2017); however, a more detailed breakdown of the way populism permeates different news formats would add nuance to this finding, adding to our understanding of media's populist tendencies. While Rooduijn (2014) concludes that letters to the editor are more populist than opinion pieces, the present study sets aside messages written by ordinary citizens, and focuses on how populist content varies between editorials, feature stories and news reports. By selecting this approach, it follows Van Dijk (1988), who distinguishes between the three types of news content according to the degree of personal opinion: While news articles do not express opinions, feature stories analyze the context or background that include a personal point of view, but not as dominant or explicitly advocating a position as editorials. However, as literature does not yield any expectations about comparing between different types, a research question is formulated instead of a hypothesis:

RQ1: Do news reports, editorials or feature stories exhibit more populism?

\section{CASE SELECTION}

The chosen arena for the case study is Macedonia. There are multiple reasons for this decision. First of all, since 2006, for eleven years the government was led by VMRO-DPMNE, a nationalist, right-wing party which during this time has been notorious for its utilization of populist discourse (Petkovski, 2014). Despite regime change in 2017, VMRO's interference in media during its time in power has caused a bitter division of major outlets along partisan lines (Belicanec \& Ricliev, 2012). The collusion between parties and media renders Macedonia a suitable case for analyzing the relationship between populism and partisan media.

Furthermore, before the Syrian refugee crisis in 2015, Macedonia had very little experience with migration, which in Western Europe, and recently some of the Eastern European countries too, has been a controversial issue, sparking anti-immigrant campaigns and restrictive policy proposals by right-wing populist politicians. After the country found itself on the Balkan migrant route, the national security issue has been employed by the ruling elite to confront opposition on the domestic front, in the context of an ongoing internal crisis. Amidst chaotic scenes on the border with Greece, the tone of VMRO has shifted to themes of danger and xenophobia (Smith \& Tran, 2016), similar to that of populist politicians in other Eastern European countries (such as Poland or Hungary), where authoritarianism, nationalism and Euroscepticism has been on the rise (Bugaric, 2008). Due to this, the Macedonia case can potentially be generalized to Eastern Europe with regards to media populism and other socio-political trends. 
Because right-wing ideology and populist rhetoric in Macedonia is monopolized by the then-ruling party, partisan media which have been supportive of VMRO's government are the likeliest to incorporate both such an ideology and rhetoric. Therefore, in the context of conflated partisan loyalty and ideological orientation, as in the case of Macedonia (see Cvetanoski, 2015), such media represent natural objects of scrutiny. I selected four outlets that are known to mirror VMRO's positions, in order to see whether they also mirror its populist style. Two are newspapers: Dnevnik, a broadsheet daily with a relatively long tradition on the news scene, and Vecer, employing a more flamboyant tabloid-style, while two are online news outlets, Kurir and Infomax, web-only outlets with a more outspoken partisan bias, especially the latter with its radical advocacy, in the model of the infamous InfoWars.

\section{METHOD}

Quantitative content analysis was performed on the four outlets, on a sample of articles $(N=409)$ compiled from two periods, the first one for three weeks in September 2015 (serving as the baseline), and the second for three weeks in March 2016, in order to observe the hypothesized increase of populist content. The rationale for the timeframes is contextual: In September 2015, the sudden migrant flow from Greece caused a shift in the focus of domestic news, marking the beginning of the crisis, while in March 2016, the crisis culminated as clashes erupted between the police and the migrants, after which the government decided to close the border with Greece. Sampling was done by the means of census data, generally considered the best form of representation when feasible (MacNamara, 2005), since the analysis covered the entire content related to migration in the abovementioned periods, identified through reviewing the total amount of articles. ${ }^{1}$

The articles were available in the online archives of the four media, which for Vecer and Dnevnik also included all the articles published in the print newspapers. In contrast to Rooduijn's (2014) strategy to only focus on commentary done by the authors themselves as distinct from politicians' populist statements only relayed by media, I considered even this type of "reproduced" content relevant. This approach is justified as different media select quotes differently depending on editorial policy, according to which they can choose to highlight more or less populist statements. By including all manifestations of populism in the analysis, whether produced or reproduced, I followed the principle of accounting for both populism $b y$ the media and populism through the media (de Vreese et al., 2018). This procedure captures populist content on aggregate, since populism that media organizations engage in themselves is only a part of the content they carry, along with providing a forum

1 Only the articles dealing with the migrants in Macedonia were considered, excluding all foreign news regarding the crisis. This was done in order to isolate manifestations of populism that exclude migrants in relation to the Macedonian people as a point of reference. 
for populist actors and disseminating messages that increase visibility and legitimacy of those actors. I have chosen entire articles as units of analysis instead of just paragraphs in order to analyze them as coherent arguments in which the populist style may appear.

\section{MEASURES}

The foundation for operationalizing the dependent variable consisted of three components, based on the theoretical framework above. First, people-centrism was evaluated for each article, by answering the question "Does the text refer to 'the people?", but also other references to the people, like "our citizens," "our country," "the society," "the nation" and "the Macedonian people" (Rooduijn, 2014). Second, the presence of exclusion was captured by identifying words like "outsiders," "invaders," "threat," "burden," "dangerous," "jihadists," etc. (Jagers \& Walgrave, 2007). Finally, an indicator was created to evaluate in each article the martial and radical stylistic disposition which politicians cannot afford (Krämer, 2014), as a combination by emotional appeal and sharp, jargon language. ${ }^{2}$ From the coding process, three corresponding categories of media populism emerge: "empty" populism, which only contains references to the people, as conceptualized by Jagers \& Walgrave (2007); "exclusionary" populism, entailing the presence of both people-centrism and exclusion (Reinemann et al., 2016), and finally "complete" media populism, as the main interest of this study, adding the stylistic element to the other two aspects in order to capture the populist style. ${ }^{3}$

Since measuring a concept like populism, with its subtle and chameleonic nature, requires a certain interpretative element, additional techniques were used to complement the above operationalization and account for its implicit aspects. Therefore, evaluating people-centrism was aided by applying Krämer's (2014, p. 49) condition of "ethnocentric schemata," where "a medium uses categories that are as close as possible to the assumed knowledge of 'common people', presented as a real-life antidote to knowledge of elites alienated from the everyday world." With this in mind, not only keywords referring to the people were counted, but also any form of in-group collective glorification through positive contextual attributions (references to the people as "honest," "hardworking," "wise," etc.). Stylistic disposition required the most intuition, because appeal to emotion can easily be confused with ordinary tabloid sensationalism, without extreme attention to context. Despite this, the inter-coder reliability between the two coders assessed with Krippendorf's alpha on a random subsample of $10 \%$ of the total articles yielded satisfactory results: for people-centrism, $\alpha=0.70$, for exclusion $\alpha=0.68$, and for stylistic disposition there was the most agreement, $\alpha=0.76$.

2 Internal consistency tests yielded a somewhat mediocre value for Cronbach's alpha $(\alpha=0.68)$. However, it is the author's judgment that given the fluid nature of the dependent variable, and its construction by adapting different theoretical perspectives, there is sufficient consistency.

3 A detailed summary of the coding procedure is available upon request. 


\section{INCIVILITY IN PARTISAN MEDIA}

The independent variable capturing the crisis' intensity (H1) was measured as dichotomous for the two periods (low and high), and the operationalization of the independent variable media type - print or online - was also straightforward as a dummy (H3). News reports, feature stories and editorials were evaluated in the same fashion (RQ1), in line with existing definitions (e.g. Van Dijk, 1988).

The level of partisanship was more complicated to measure. In order to make a distinction between the intensity of partisan bias in favor of the ruling party among the four media, I used the level of incivility, as described in the theoretical section. By following Gervais' (2014, p. 569) approach, I identified four criteria which make an article uncivil, which served as coding instructions: first, "name-calling, mockery and character assassination," characterized by additional, superfluous adjectives that do not add information but are purposefully insulting, belittling and condescending; second, "spin and misrepresentative exaggeration," characterized by use of extreme, inflammatory words or phrases that makes action seem more radical, immoral or corrupt; third, "histrionics," where language suggests an individual or group should be feared or is responsible for sadness; and finally fourth, "conspiracy theory," e.g., accusations of very sinister motives/actions/background, although unreasonable, presented as factual. ${ }^{4}$

If any of the criteria were present, I considered an article uncivil, thereby making a rigid distinction between civility and incivility. Thus I created a dummy variable which was coded zero if it did not fulfill any of the criteria for incivility, and one, if it contained at least one of the criteria. I have chosen a separate sample of articles from all four outlets $(N=117)$, by selecting all the political news stories they had on a random day (March 1,2016), and coded for incivility. All outlets had published a similar amount of articles on that day (Dnevnik published 30, Vecer 34, Kurir 26 and Infomax 27). The inter-coder reliability test was performed on 20 articles, with high agreement between the two coders $(\alpha=0.94)$.

The results have shown that newspapers are less uncivil. Vecer is the least uncivil outlet (i.e., most civil) from all four, with $88.2 \%$ of articles not containing any incivility, while Dnevnik is slightly more uncivil with $80 \%$ of civil articles. For the online news outlets, $69.2 \%$ of Kurir's articles were civil, and 30.8 were uncivil, while expectedly, Infomax is by far the most uncivil media outlet, with $37 \%$ civil and $63 \%$ uncivil articles. Accordingly, for the independent variable partisanship (H2), I ranked the four media outlets in the partisan bias scale according to their incivility scores.

\section{RESULTS}

Initial tests indicated that there is indeed a difference between the amount of populist discourse in media during the first and the second period of observation.

4 The full codebook is available upon request. 
If the amount of total articles that showed no populism at all in September 2015 was $81.1 \%$, in March 2016 this amount is down to $70.4 \%, \chi^{2}(1, N=409)=6.326$, $p=.012$. There are significant differences between the two periods for two out of the three operationalizations of populist content, the only exception being "empty" populism, whose presence in the news does not significantly differ between September and March, $\chi^{2}(1, N=409)=2.002, p=.157$. This is unsurprising, as any tendency for more populist coverage of migration would likely include some form of exclusion in addition to references to the people. Indeed, this is reflected by the significant increase in the levels of "exclusionary" populism as the migrant crisis spiralled between September and March, $\chi^{2}(1, N=409)=6.351, p=$ .012. Most importantly, the percentage of articles containing all three elements of populism, capturing the right-wing populist style, grew from $6.1 \%$ in September to almost double, $11.7 \%$ in March, $\chi^{2}(1, N=409)=3.911, p=.048$. These findings lend support for $\mathrm{H} 1$. Table 1 shows the full distribution of populism levels across the two periods.

Table 1. Populist style in Macedonian media over two time periods

\begin{tabular}{|c|c|c|c|c|c|}
\hline Period & & $\begin{array}{c}\text { Empty } \\
\text { populism }\end{array}$ & $\begin{array}{c}\text { Exclusionary } \\
\text { populism }\end{array}$ & $\begin{array}{c}\text { Complete } \\
\text { populism }\end{array}$ & Total articles \\
\hline \multirow{2}{*}{ September 2015 } & Count & 11 & 14 & 12 & 196 \\
\cline { 2 - 6 } & Percent & 5.6 & 7.1 & 6.1 & \\
\hline \multirow{2}{*}{ March 2016 } & Count & 6 & 32 & 25 & 213 \\
\cline { 2 - 6 } & Percent & 2.8 & 15.0 & 11.7 & \\
\hline
\end{tabular}

Note: Cells represent the number of articles within each populism type and their percentage from the total number of articles in the given period.

Source: Author.

A curious pattern emerges when comparing the amount of populist discourse in media outlets according to their levels of partisan bias. Chi-square tests reveal a significant difference between the amount of "empty" and "complete" populist articles across outlets, but not "exclusionary" populist articles. However, the manifestations of "empty" populism do not follow the hypothesized pattern: only references to the people are encountered significantly more often in the less partisan outlets (6.9\% in Vecer, $7.0 \%$ in Dnevnik) than in the more partisan outlets (1.0\% in Kurir, $1.1 \%$ in Infomax), $\chi^{2}(1, N=409)=8.935, p=.030$. Of greater interest is the comparison on "complete" populism, where extreme right-wing outlet Infomax is the outlier driving the significant difference, with $21.7 \%$ of its articles showing all populist traits. However, contrary to expectations, the amount of articles displaying the complete populism in Vecer (6.9\%) 
and Dnevnik (6.1\%) is bigger than in Kurir (3\%). Figure 1 visually displays the differences between the four outlets, ordered by their level of partisanship (as ranked by incivility), suggesting a lack of evidence for $\mathrm{H} 2$. The above findings reflect on the breakdown of populist content by media type; contrary to expectations, traditional print newspapers utilize significantly more "empty" populism than online news outlets, $\chi^{2}(1, N=409)=8.931, p=.003$, while there is also a marginally significant difference between traditional and online media when it comes to "complete" populism, $\chi^{2}(1, N=409)=3.660, p=.056$. However, it is the highly populist nature of Infomax that is causing the significantly greater presence of complete populism in online media (Table 2). This, coupled with the lack of significant difference across media types for exclusionary populism, yields no support for $\mathrm{H} 3$ about the difference in the use of populist style between newspapers and online outlets.

Three logistic regression models illuminate the multivariate relationship between the predictors and each operationalization of populism as dependent variable, as presented in Table 3. The use of odds ratios (OR) is to facilitate coefficient interpretation. First of all, the analysis confirms that the probability of populist content does not depend on whether the outlet is traditional or online for any category of populism, rendering $\mathrm{H} 3$ conclusively false - there isn't a significant difference between media populism in traditional and online media. However, all other variables held constant, the odds that news content from March 2016 exhibits exclusionary populism are 2.32 times greater than

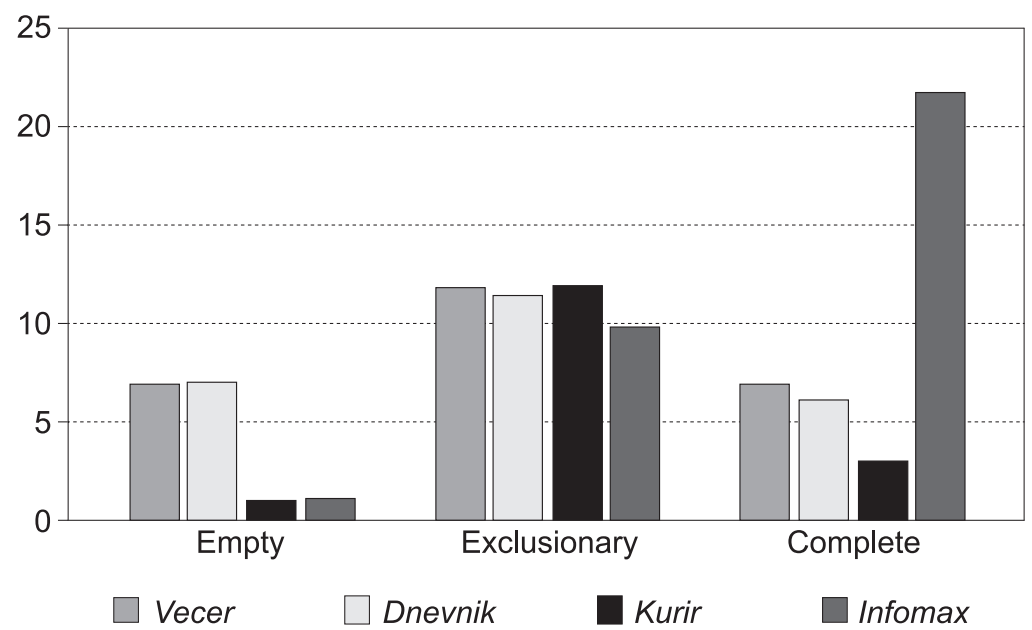

Figure 1. Populism per outlet incivility

Note: $y$-axis represents the percentage of total articles exhibiting empty, exclusionary and complete populism for each outlet (maximum displayed is $25 \%$ ).

Source: Author. 
Ivo Bosilkov

Table 2. Populism in different types of Macedonian media

\begin{tabular}{|c|c|c|c|c|c|}
\hline \multirow{2}{*}{ Media type } & & $\begin{array}{c}\text { Empty } \\
\text { populism }\end{array}$ & $\begin{array}{c}\text { Exclusionary } \\
\text { populism }\end{array}$ & $\begin{array}{c}\text { Complete } \\
\text { populism }\end{array}$ & Total articles \\
\hline \multirow{2}{*}{ Traditional } & Count & 15 & 25 & 14 & 216 \\
\cline { 2 - 6 } & Percent & 6.9 & 11.6 & 6.5 & \\
\hline \multirow{2}{*}{ Online } & Count & 2 & 21 & 23 & 193 \\
\cline { 2 - 6 } & Percent & 1.0 & 10.9 & 11.9 & \\
\hline
\end{tabular}

Note: Cells represent the number of articles within each populism type and their percentage from the total number of articles in the particular media type.

Source: Author.

Table 3. Logistic regression explaining populism in Macedonian media

\begin{tabular}{|l|c|c|c|}
\hline \multicolumn{1}{|c|}{$\begin{array}{c}\text { Predictors } \\
\text { of media populism }\end{array}$} & Empty populism & Exclusionary populism & Complete populism \\
\hline & OR $(S E)$ & OR $(S E)$ & OR $(S E)$ \\
\hline Constant & $0.11(0.05)^{* * *}$ & $0.07(0.03)^{* * *}$ & $0.01(0.01)^{* * *}$ \\
\hline March 2016 & $0.36(0.19)^{\star}$ & $2.32(0.79)^{* *}$ & $1.83(0.74)$ \\
\hline Partisan bias & $0.82(0.44)$ & $0.78(0.25)$ & $2.18(0.91)^{*}$ \\
\hline Online media & $0.17(1.27)$ & $1.52(1.08)$ & $0.41(0.37)$ \\
\hline Feature article & $0.52(0.56)$ & $2.11(0.89)^{*}$ & $5.92(2.96)^{* * *}$ \\
\hline Opinion article & $4.64(2.88)^{* * *}$ & $1.85(0.83)$ & $14.08(6.30)^{\star * *}$ \\
\hline$\chi^{2}$ & 19.23 & 10.84 & 56.71 \\
\hline log likelihood & -61.10 & -138.40 & -95.82 \\
\hline Pseudo R2 & 0.14 & 0.04 & 0.23 \\
\hline$N$ & 409 & 409 & 409 \\
\hline
\end{tabular}

Notes: $O R=$ odds ratio; $S E=$ standard error.

Two-tailed test. Dependent variable is a binary indicator of a different type of populism (in each column). SEs reported between parentheses. The reference category for a feature article and opinion article is the news report.

${ }^{*} p<.10{ }^{* *} p<.05{ }^{* * *} p<.001$.

Source: Author.

the odds that news content from September 2015 is exclusionary populist (95\% $C I[1.39,4.16])$. Since this pattern isn't replicated for complete populism, and even contradicted for empty populism (albeit with marginal significance), it can be concluded that $\mathrm{H} 1$ is only partially supported. With regards to $\mathrm{H} 2$, the odds ratio for partisan bias is positive for all three categories of populism, and marginally significant for complete populism $(O R=2.18, p=0.062,95 \% C I$ $[0.97,4.64])$. In substantive terms, this means that for every increase of media 
partisanship by one unit (in this case the specific outlet), the odds of complete populism in news content increases by a factor of 2.18 . This yields tentative support for $\mathrm{H} 2$ stating that the greater the partisan bias of a particular outlet, the more populist it will be, when all three populism components are present. However, caution should be exercised, as the increase of probabilities that an article will have "complete" populist style with greater partisan bias isn't exactly linear.

Finally, addressing RQ1, there is clear evidence that ceteris paribus, both feature $(O R=5.91, p<0.001,95 \% C I[2.22,15.76])$ and opinion articles $(O R=14.08$, $p<0.001,95 \% C I[5.86,33.85])$ are more likely to have all three elements of media populism than news reports. Opinion articles also have significantly greater odds of being "empty" populist than news reports, $O R=4.63, p=0.014,95 \% C I[1.37$, 15.69], although this isn't the case for features. This indicates that populist style is much less likely to be expressed when the constraints of news reporting are enforced.

\section{DISCUSSION AND CONCLUSION}

As the intersection of political parties' populism supply and the public's demand occurs in the public arena, this study adds to a growing body of literature that shows how media are the successful carrier of populism, discovering important aspects of how the populist "Zeitgeist" operates outside of political actors. Instead of analyzing media populism as a general phenomenon, this study focused on a single issue which ranks among the highest on the populist right-wing agenda, and analyzed it in a novel context of a right-wing dominated Eastern European society, yet one that until recently was largely abstracted from this specific issue. This study confirms that discourse on migration, as an issue "owned" by right-wing populist actors (Walgrave \& De Swert, 2007), has assumed more substantive and stylistic features of exclusionary populism as the crisis developed. This populist style inherent in anti-immigrant rhetoric is also expressed in the media, and is a testament to the diffusion of populist logic in the public sphere. However, to confirm the robustness of this finding beyond the case study, a comparative perspective would be needed. Furthermore, it would also be relevant to measure how much of it can be attributed solely to media and how much of it originates from politicians.

The study's findings suggest that with the decrease of civility of partisan media (as a benchmark for their bias level), their populist style increases. Sobieraj and Berry (2011) claim that, in order to understand how political discourse shapes attitudes about politics, the texture of our broader political culture must be considered. If opinionated media reproduce the style of populist politicians with the objective of reaching partisan oriented audiences, they are also actively promoting a populist worldview along with the ideological one. The proliferation of this worldview in political culture can be damaging to democracy, as it may reinforce political cynicism and authoritarian impulses among citizens, especially if combined with incivility. 
Although there are some indications of a link between right-wing partisan media and the populist style, evidence that online outlets are more populist than traditional print media is scarce. While Infomax is an example that news websites can integrate more populist features in their content, Kurir shows they do not necessarily have to. While on the one hand this may indicate that convergence tendencies are making the differences between the two types of media more blurred, this conclusion comes with a warning: The number of media analyzed here is limited. While the outlets are among the top sources of political news in Macedonia (Dnevnik has the largest newspaper circulation among broadsheet papers in the country, according to the Media Sustainability Index [IREX, 2015], and Kurir ranks among the highest for the online audience of political news according to tracking tool Gemius), perhaps a more exhaustive comparison of outlets is required to make more robust inferences. In contrast to the ambiguity of this finding, the study delivers solid proof that opinion articles such as editorials or features contain more populism than news reports, implying that while opinionated media increasingly emphasize advocacy as virtue, they refrain from embedding a populist style in "hard" news. Yet, this finding is indicative of the general shift to interpretative journalism, which has been connected to media negativity, people centrality, conflict and distrust in the establishment (Djerf-Pierre \& Weibull, 2008). The possibility that the populist style of politics might push media further away from neutral and factual reporting is one that requires further investigation, especially given how the surge of hyperpartisan fake news facilitates the rise of populist politicians.

Despite the breakthroughs this study makes in the field of media populism, it is far from perfect. Inter-coder reliability for the dimensions of populism is achieved with the aid of only one other coder apart from the author. Moreover, the complex measurement procedure requires a solid degree of familiarity with the concept which needs to be combined with a quasi-interpretative approach in order to achieve a relatively accurate account of populism levels. This is a likely reason why alphas reach barely the minimum level (none of them reach 0.80 , which is generally considered the required level of inter-coder reliability). Apart from reliability, certain decisions in the design could potentially hamper the validity levels too. For the most part, text length is absorbed by the distinction between types of articles, seeing that editorials and features are usually longer than news reports. However, this is not always the case, and article length could affect levels of populism simply due to the sheer quantity of content where populist discourse can be embedded. Although this is partly accounted for by considering the entire texts as units of analysis, a quantitative approach can always yield inconsistencies in the measurement of an elusive concept like populism.

It must be also recognized that establishing partisan bias through measuring incivility is a somewhat rudimentary approach despite its originality; such a strategy makes it difficult to develop a perfect interval scale, and instead can only serve as an orientation device for a select number of media. This is a clear limitation, reflected by the fact that the populist style in the analyzed outlets does not increase linearly with their established level of partisan bias via incivility. It should therefore be a 
priority for future research to further clarify the distinction between media incivility, partisanship, and populism.

The most important measurement-related problem is the omission of anti-elitism, as a crucial element of thick populism (Jagers \& Walgrave, 2007). Although resentment of the establishment is a fundamental tenet of populism, the main distinctive feature of exclusionary right-wing populism in Europe is the horizontal comparison of "the people" to immoral out-groups, such as minorities and immigrants (Reinemann et al., 2016). Regardless, an ideal operationalization that would tap "thick" populism should involve both these elements. On numerous occasions throughout the analysis, hostility has been encountered towards the evil elites as well, embodied by Greece (in context of the name dispute between the two countries), the former communists comprising the liberal left party in Macedonia, and even the European Union. Accounting for this aspect too would yield an even more complete picture of media populism and its style, as would a longer time frame for study, which would also show whether the recent electoral defeat of the right-wing populist party in Macedonia has affected populist discourse in the media.

Addressing these deficiencies is a challenge for future research. Regardless of their existence, the implications of the findings are important, as they draw attention to a complex interaction between partisan media, right-wing politicians and populism, which can ultimately reflect on citizens' attitudes, especially in the context of a mediatized threat from migration. According to Norris (1999), repeated and steady exposure to news media content could have a diffuse influence on attitudes and opinions, like a slow socialization process. The possibility for further polarization of the public as a result of selective exposure to partisan media is a reason for concern (Stroud, 2010), especially if a highly resonating populist style exacerbates this relationship.

\section{REFERENCES}

Akkerman, A., Mudde, C., \& Zaslove, A. (2013). How populist are the people? Measuring populist attitudes in voters. Comparative Political Studies, 47(9), 1324-1353.

Allan, S. (2002). Reweaving the internet: Online news after September 11. In B. Zelitzer \& S. Allan (Eds.), Journalism after September 11 (pp. 119-139). New York: Routledge.

Alvares, C., \& Dahlgren, P. (2016). Populism, extremism and media: Mapping an uncertain terrain. European Journal Of Communication, 31(1), 46-57.

Barr, R. (2009). Populists, outsiders and anti-establishment politics. Party Politics, 15(1), 29-48.

Baum, M., \& Groeling, T. (2008). New media and the polarization of American political discourse. Political Communication, 25(4), 345-365.

Belicanec, R., \& Ricliev, Z. (2012). Mapping digital media: Macedonia. Open Society Media Program, 4-84. Retrieved from https://www.opensocietyfoundations.org/uploads/960d8b50-c9e6-48b48745-ab68d682b5f9/mapping-digital-media-macedonia-20120625.pdf.

Bos, L., \& Brants, K. (2014). Populist rhetoric in politics and media: A longitudinal study of the Netherlands. European Journal of Communication, 29(6), 703-719.

Bugaric, B. (2008). Populism, liberal democracy, and the rule of law in Central and Eastern Europe. Communist and Post-Communist Studies, 41(2), 191-203. 
Canovan, M. (1999). Trust the people! Populism and the two faces of democracy. Political Studies, 47(1), 2-16.

Causidis, T., \& Sekulovski, D. (2013). Macedonia: "Critical media is vanishing". Index on Censorship. Retrieved May 27, 2016, from https://www.indexoncensorship.org/2013/11/macedonia/.

Cvetanoski, I. (2015). Journalism in Macedonia: The awful truth. Osservatorio Balkani e Caucaso Transeuropa. Retrieved May 27, 2016, from https://www.balcanicaucaso.org/eng/Areas/Macedonia/ Journalism-in-Macedonia-the-awful-truth-163490.

de Vreese, C., Esser, F., Aalberg, T., Reinemann, C., \& Stanyer, J. (2018). Populism as an expression of political communication content and style: A new perspective. International Journal of Press/ Politics, 23(4), 1-16.

Djerf-Pierre, M., \& Weibull, L. (2008). From public educator to interpreting ombudsman. In J. Stromback, M. Orsten, \& T. Aalberg (Eds.), Communicating politics (pp. 195-214). Gothenburg: Nordicom.

Gervais, B. (2014). Following the news? Reception of uncivil partisan media and the use of incivility in political expression. Political Communication, 31(4), 564-583.

Gidron, N., \& Bonikowski, B. (2013). Varieties of populism: Literature review and research agenda. Working Paper Series, Weatherhead Center for International Affairs, Harvard University, no. 130004. Retrieved December 2, 2018, from https://scholar.harvard.edu/files/gidron_bonikowski_ populismlitreview_2013.pdf.

Hallin, D., \& Mancini, P. (2012). Comparing media systems beyond the Western world. Cambridge: Cambridge University Press.

Hameleers, M., Bos, L., \& de Vreese, C. (2017). Shoot the messenger? The media's role in framing populist attributions of blame. Journalism, online first, 1-20. https://doi.org/10.1177/1464884917698170.

Hawkins, K. (2009). Is Chavez populist? Measuring Populist discourse in comparative perspective. Comparative Political Studies, 42(8), 1040-1067.

Herbst, S. (2010). Rude democracy. Philadelphia: Temple University Press.

IREX (2015). Macedonia Media Sustainability Index 2015. Retrieved May 27, 2016, from https://www. irex.org/resource/macedonia-media-sustainability-index-msi.

Jagers, J., \& Walgrave, S. (2007). Populism as political communication style: An empirical study of political parties' discourse in Belgium. European Journal of Political Research, 46(3), 319-345.

Jamieson, K., \& Cappella, J. (2009). Echo chamber. New York: Oxford University Press.

Jamieson, K., \& Hardy, B. (2012). What is civil engaged argument and why does aspiring to it matter? PS: Political Science \& Politics, 45(3), 412-415.

Kazin, M. (1995). The populist persuasion: An American history. Ithaca: Cornell University Press.

Krämer, B. (2014). Media populism: A conceptual clarification and some theses on its effects. Communication Theory, 24(1), 42-60.

Levendusky, M. (2013). Why do partisan media polarize viewers? American Journal of Political Science, 57(3), 611-623.

MacNamara, J. (2005). Media content analysis: Its uses, benefits and best practice methodology. Asia Pacific Public Relations Journal, 6(1), 1-34.

Matheson, D. (2004). Weblogs and the epistemology of the news: Some trends in online journalism. New Media \& Society, 6(4), 443-468.

Mazzoleni, G. (2008). Populism and the media. In D. Albertazzi \& D. McDonnell (Eds.),Twenty-first century populism (pp. 49-67). New York: Palgrave.

Mazzoleni, G., Stewart, J., \& Horsfield, B. (2003). The media and neo-populism. Westport, Conn.: Praeger.

Meny, Y., \& Surel, Y. (2000). Par le peuple, pour le peuple. [Paris]: Fayard.

Moffitt, B., \& Tormey, S. (2014). Rethinking populism: Politics, mediatisation and political style. Political Studies, 62(2), 381-397.

Mudde, C. (2004). The populist Zeitgeist. Government \& Opposition, 39(4), 542-563. 
Mudde, C., \& Rovira Kaltwasser, C. (2011). Populism in Europe and the Americas. Cambridge: Cambridge University Press.

Norris, P. (1999). On message. London: SAGE.

Petkovski, L. (2014). Government's PR: Who are Gruevski's people? NVO Infocentar. Retrieved May 23, 2016, from http://nvoinfocentar.mk/en/pr-na-vladata-koj-e-narodot-na-gruevski/.

Reinemann, C., Aalberg, T., Esser, F., Strömbäck, J., \& de Vreese, C. (2016). Populist political communication: Towards a model of its causes, forms and effects. In T. Aalberg, F. Esser, C. Reinemann, J. Strömbäck, \& C. de Vreese (Eds.), Populist political communication in Europe (pp. 12-29). London: Routledge.

Rooduijn, M. (2014). The mesmerising message: The diffusion of populism in public debates in Western European media. Political Studies, 62(4), 726-744.

Rydgren, J. (2005). Is extreme right-wing populism contagious? Explaining the emergence of a new party family. European Journal of Political Research, 44(3), 413-437.

Saura L., \& Enli, G. S. (2011). Commercial television: Business in transition. In J. Trappel, W. A. Meier, L. d'Haenens, J. Steemers, \& B. Thomass (Eds.), Media in Europe today (pp. 79-95). Bristol, UK: Intellect.

Singer, J. (2003). Who are these guys? The online challenge to the notion of journalistic professionalism. Journalism, 4(2), 139-163.

Smith, H., \& Tran, M. (2016, February 29). Teargas fired as refugees try to breach Greek-Macedonian border. The Guardian. Retrieved May 23, 2016, from http://www.theguardian.com/world/2016/ $\mathrm{feb} / 29 /$ teargas-fired-as-refugees-try-to-breach-greece-macedonia-border.

Sobieraj, S., \& Berry, J. (2011). From incivility to outrage: Political discourse in blogs, talk radio, and cable news. Political Communication, 28(1), 19-41.

Stroud, N. (2010). Polarization and partisan selective exposure. Journal of Communication, 60(3), 556-576.

Sunstein, C. (2009). Going to extremes. Oxford: Oxford University Press.

Surmava, T. (2014). Macedonia:Elections and nationalism. Projectfordemocraticunion. Retrieved May 28, 2016, from http://www.democraticunion.eu/2014/05/macedonia-elections-and-nationalism/.

Taggart, P. (2000). Populism. Buckingham, UK: Open University Press.

Thorbjornsrud, K. (2015). Framing irregular immigration in Western media. American Behavioral Scientist, 59(7), 771-782.

Trappel, J., \& Enli, G.S. (2011). Online media: Changing provision of news. In J. Trappel, W. A. Meier, L. d'Haenens, J. Steemers, \& B. Thomass (Eds.), Media in Europe today (pp. 97-113). Bristol, UK: Intellect.

Van Dijk, T. (1988). News analysis. New Jersey: LEA.

Walgrave, S., \& De Swert, K. (2007). Where does issue ownership come from? From the party or from the media? Issue-party identifications in Belgium, 1991-2005. The International Journal of Press/ Politics, 21(1), 37-67. 